year, and has hardly yet ceased; 80 per cent. of the inhabitants of this city, Europeans as well as natives, having been attacked. The mortality, however, has been very small, not greater than it is in measles at home. It is really a West Indian disease, called out there, I believe, the 'Dandy, or 'Break-bone' fever. It has never been known in such a severe epidemic form in India before last year. There were a few cases about twenty years ago; none since the present epidemic. It is a sort of mixture of scarlet fever and rheumatism-i.e., intense pains in the joints, with a red rash, passing off in a few days, the whole attack not lasting longer than a week, but pains of a rheumatic character remaining for a long time after. With me the attack commenced with a kind of nervous exhaustion and depression, which passed off after a short trip to sea, with bathing in salt water. Shortly after my return to Calcutta, in April, as the heat increased the old symptoms returned, attended with a breaking out of a perfect mass of huge boils like carbuncles, confining me to bed and to the house for three weeks, unable to move without agony, losing sleep, appetite, and flesh, becoming quite nervous and broken down. I was recommended to pay a visit to the Himalayas, and returned after a month's absence convalescent. As soon as I reached the colder climate my symptoms rapidly disappeared. I am now quite well, and able to attend to my duties."

No further particulars are mentioned.

I am, Sir, your obedient servant,

F. Adams Dafson, M.D.

Roseville, Dartmouth, 8th Oct. 1872.

\section{TYPHOID FEVER IN INDIA.}

\section{To the Editor of THE LANCET.}

Sir,-I have read Dr. De Renzy's letter in The LanceT of the 5th inst. The issue between us, reduced to its ultimate terms, is this: Shall medical "science, in questions of grave diagnosis, require the published well-digested elinical reports of actual observers, or be satisfied with the inferences drawn by eminent statisticians from hospital cases and hospital returns? I hold to the first. Dr. De Renzy, if I understand him aright, is content with the second. Thus, so far as I am concerned, the matter must rest.

In respect to what $I$ have at different times written on fevers in India, I can only hope that all who care to know my opinions will go to the original sources, and not accept them at second-hand, garbled and misinterpreted.

I am, Sir, your obedient servant,

Edinburgh, October 9th, 1872.

C. MoReheAd, M.D.

\section{INFECTION AT SCARBOROUGH. To the Editor of THE LANCET.}

SiR,-During a recent visit to Scarborough, I entered into conversation with a person who kept a lodging-house, as to the sanitary condition of the town in general, and lodgings in particular. He informed me (unwillingly) that a few months since, when small-pox was raging in the town and neighbourhood, his daughter was taken ill of that complaint, and that, though knowing this, he kept her in the house in a room to herself, but let his lodgings to a party of six persons who had come to Scarborough for their health. He kept the first of his daughter's illness a secret, and (though he confessed that he was breaking the law) he took visitors into his house in which, at the time, there was an infectious disease. He also informed me that plenty of lodging-house keepers did the same thing. If the above be true (which I have no reason to doubt), no wonder visitors return from this favourite health-resort with the germs of deadly disease sown in their systems. It also speaks very badly for the administration of sanitary regulations. I need add no more; the fact speaks for itself. If, however, my communication leads to stricter and better inspection of all lodging-houses, both in Scarborough and elsewhere, I shall be satisfied.

I am, Sir, yours faithfully,

Oetober 1st, 1872

MEDICUS

\section{GRAPHIC PORTRAITURE.}

To the Editor of THs LANCET.

SIR,-Having declined to forward my portrait and biography to the editor of the Graphic, I was prepared to be "sent to Coventry" by that gentleman, but certainly did not anticipate having to "tarry at Jericbo until my beard was grown." This appears to be necessary, however, as the editor has put a razor to $\mathrm{my}$ chin for the first time during the last two years.

Cavendish-place, Oct. 8 th, 1872 .

Yours obediently, Christopher Heate.

\section{AN APPEAL}

To the Editor of The LaNceT.

Sir,-Knowing how ready you are to open your columns to the cry of distress, I venture to ask your aid in favour of the two daughters of the late Dr. John Hawkins, of Woodstock. He died in November, 1871, at the age of eighty. seven, having been elected a pensioner at the IMedical College, Epsom, in May, 1870. He had outlived his practice, his friends, and his savings. His two daughters are now kept from absolute starvation by the charity of a few residents of Woodstock. The ladies are in feeble health, and far too advanced in years to maintain themselves by their own exertions.

Subscriptions for their benefit will be thankfully received by Colonel Thomas, Woodstock House, Woodstock, or by Your obedient servant, J. Lumsden Propert.

100, Gloucester-place, Portman-square, W.

\section{ABERDEEN.}

(From our own Correspondent.)

WE are now furnished with "our little bill" for the ex. penses of the Small-pox Hospital. It amounts to a good deal over $\$ 3000$, and considering that only 230 patients were treated in it, and that it was in use for a period of only about seven months, it must be admitted that the cost is very heavy. No doubt a portion of this is for the purchase of the building; but as the house, being unsuited for a permanent hospital both from its nature and situation, will in all probability be sold again, we are deprived of the hope that a portion of the outlay might be carried to the credit of the next epidemic. Allowing for the sum that may be obtained by the sale of the present building, the cost of the 230 cases treated would be about $£ 10$ each; and considering that each patient was, on an average, three weeks in the house, the weekly cost of each amounted to over $£ 3$, or at the rate of rather more than $£ 170$ per patient per annum-a figure which, compared with ordinary hospital expenditure, is certainly excessively high. Whether any portion of this extravagant cost might have been saved by more economical arrangements, it is useless to inquire; it is plain that the hand-to-mouth plan of hastily providing for an epidemic after it has begun is by far the most costly that can be tried, and it is to be hoped that the lesson thus taught will not be hastily forgotten. Sume years ago one of the parochial boards here came into possession (by the compromise of a lawsuit) of a sum of about $£ 7000$ or $\$ 8000$, and it was proposed to devote about the half of it to the erection of an epidemic hospital. Reasonably enough, the other parochial board, which comprises the western half of the town, was asked to assist in the plan by contributing a trifling sum, which would not have amounted at the utmost to half-a-crown from each ratepayer, and that spread over four or five years; but, with the penny-wise-pound-foolish wisdom so of ten exhibited by such boards, all co-operation was refused, and the scheme fell to the ground. To listen to the reasons then given for that refusal, one would almost have thought that the sapient members of the board believed that an epidemic was bound to respect the boundaries of their parish, or that, like a pauper, it could be got rid of by some ingenious law of settlement. It is not too much 